\title{
Inclusion of the Corporate Income Tax Revenue into the Municipal Budget: Needs, Risks, and Solutions
}

\author{
Biruta Pūle* \\ Department of Finance, BA School of Business
}

\begin{abstract}
The author assesses the opportunities for inclusion of the corporate income tax into the budgets of the local governments on whose territories there are legally registered companies. For this purpose the same territorial code principle is recommended, which is applied to administer personal income tax. In order to motivate companies to register legally and engage in business activities in the regions of Latvia, tax incentives should be established. The application of tax incentives need to be delegated to the local governments, thus ensuring their interest in business development in their territories. The diversion of corporate income tax into the budgets of local governments would significantly strengthen their budget revenue base, increasing the interest of municipalities into the development and modernization of the companies, as well as creation of new jobs. Inherent risks are defined, and possible solutions how to eliminate these risks are suggested.
\end{abstract}

Key words: Corporate income tax, municipal government budget, tax incentives, business development, stimulation of regional economic development.

\section{Introduction}

Balanced and sustainable development of regions is an integral part of the overall growth of the country. On the basis of such development lies purposefully designed regional development policy, regional development planning and purposeful progress in accordance with the strategy laid down. Development planning in Latvia is organized on four levels: on the national level - by implementing the national reform "Europe 2020" (2010) strategies; on the regional level - in five planning regions, which have been formed on the basis of mutual agreement between the administrative regions and major towns; on the level of regions, planning is implemented by the administrative regions, but on the local level by local governments - municipalities, counties and cities, which draw up their development plans, involving local communities into decision making (Eiropas Komisija, 2010).

Every region of the country should be regarded as a unique territorial unit, which adds its specific characteristics to the total public image of the country. In order to maintain their characteristic features and to promote further growth, it is necessary to pay special attention to efficient development of regional territories and welfare of the population. Meeting these objectives involves two aspects which should be mentioned. The first aspect is linked with sustainable development of rural and urban territories in five regions of Latvia (Kurzeme, Vidzeme, Latgale, Zemgale and Riga) and with efficient use of their specific advantages and forces which promote economic development in order to ensure the overall growth of the country, while coordinating the economic activities with the conservation and enhancement of its natural and cultural heritage. The second aspect follows from the different features of rural and urban territories. The main focus should be laid on the economic and social cohesion that can ensure balanced development of the state and its different social groups during the period of economic recovery, as well as provide for the multiplier effect throughout the country (Latvijas ilgtspējīgas ..., 2008).

Unfortunately, the differences in pay and hence the gap in living standards between Riga and the rest of Latvia during the last five years (2007-2012) have not decreased but even increased in many areas. This is evidenced by the correlation of regional differences in such indicators as:

- employment;

- the average income level;

- number of enterprises in relation to population. 
While implementing the Community Lisbon Programme, the contribution of the tax and customs policies to the Lisbon Strategy was formulated in the Communication from the Commission to the European Council and the European Parliament (Eiropas Kopienu ..., 2005) noting that tax policy initiatives can effectively and expeditiously stimulate business environment. Tax policy has a proactive role in boosting growth of knowledge and innovations. Both research and development, as well as the general business environment could benefit from targeted fiscal measures. Taxation helps to promote environmental changes as well, leading to more sustainable production and consumption patterns (Eiropas Kopienu ..., 2005).

The Tax Policy Strategy of the Ministry of Finance for the period from 2011-2014 (LR Finanšu ministrija, 2011) raises as one of the most important challenges the motivation of local governments for the development of business environment, stating that the Ministry of Finance together with the Latvian Association of Local Governments, Latvian Employers' Confederation, Latvian Chamber of Commerce and other business organizations in 2012 is to develop proposals on how local governments could be encouraged to create an attractive business environment by the help of tax policies (Ministru kabinets, 2011).

The aim of the study: To assess the opportunities for inclusion of corporate income tax into the budgets of local governments on whose territories are legally registered companies.

The objectives of the study: (1) to analyse the needs of diversification of the local government revenue sources; (2) to identify the potential risks of inclusion of corporate income tax into local government budgets; (3) to explore possible solutions.

The object of the study: Local government budget revenue sources.

The subject of the study: Corporate income tax as an effective local government revenue source which stimulates business environment.

Research hypothesis: The inclusion of the corporate income tax into local government budgets will promote the interest of local governments into promotion of business activities of enterprises located on the territory of the municipality.

\section{Materials and Methods}

To study the interrelationships of problem elements and their synthesis, monographically descriptive method has been applied, as well as analysis and synthesis techniques. Scientific (inductive) method has been used to compile isolated facts and opinions into general findings and correlations. Method of deduction has been used for theoretical explanation and logical synthesis of data acquired during the empirical research. Dynamic analysis method, data grouping method, constructive calculation method and statistical graphics method have been used for data analysis.

\section{Results and Discussion \\ The need to diversify the sources of the local government budget revenue}

The different levels of Latvian regional development negatively affect the economic growth in the country. There are no such territories in Latvia which do not have potential for economic growth altogether, yet the diversity is great in the presentday situation. There exist socioeconomic regional differences - environmental and cultural nuances, differences in traditions and in economic activities, as well as income diversity. Regional development is unbalanced, and local advantages are not put to use. Latvia is becoming a highly monocentric state with a fragmented administrative and territorial system (Latvijas ilgtspējīgas ..., 2008).

The term sustainable development was defined in the report "Our Common Future" of the World Commission on Environment and Development, established by the United Nations (1987), where for the first time the global development scene was analyzed and described, showing the deadlock where the world would find itself if changes do not take place in political thinking. At the end of the 80ies of the 20th century, important international political processes began in the world marking the start of a new way of thinking. Sustainable development was defined as a continuous, deliberate and logically conducted process of social changes on global, regional and local levels aiming to provide for today's needs without endangering meeting the needs of future generations (Organisation for Economic ..., 2006).

Development is a quality concept which includes ideas for improvement and progress, as well as the development of the cultural, social and economic spheres. Although up to now, the Latvian economic growth has been rapid enough, there still exist limiting factors in the Latvian economy which may impede future economic growth. Therefore, to ensure a balanced and sustainable growth, one of the tasks of the government is to reduce the existing disparities 


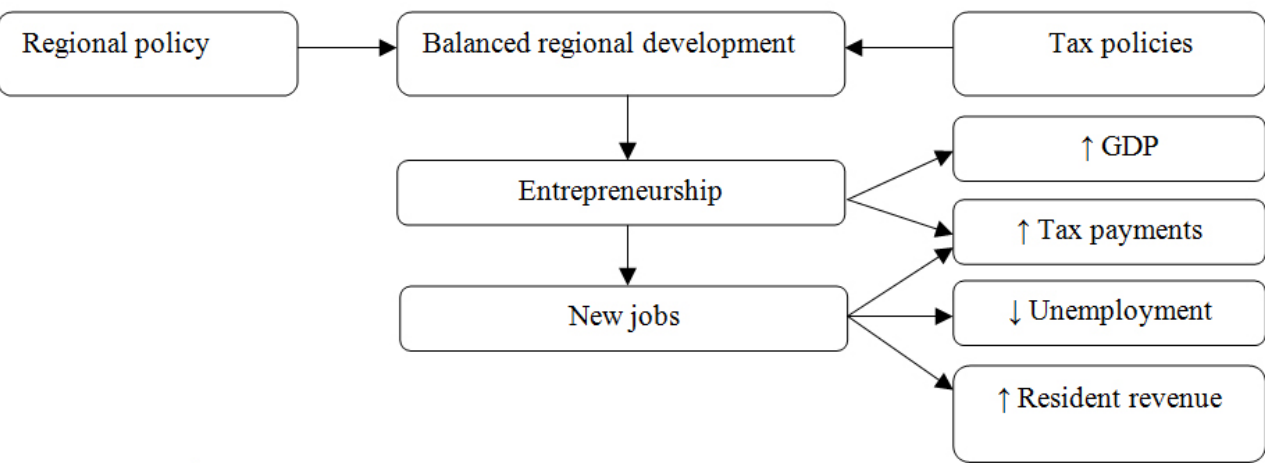

Source: Valsts reǵionālās ..., 2011.

Fig. 1. Regional policy and tax policy correlation.

Table 1

Total tax revenue in local budgets in Latvia in 2007-2010, million LVL

\begin{tabular}{ccccc}
\hline Year & Personal income tax & Real estate tax & Lottery and gambling tax & Natural resource tax \\
\hline 2007 & 701.1 & 74.3 & 7.3 & 2.8 \\
\hline 2008 & 830.6 & 70.7 & 7.1 & 3.1 \\
\hline 2009 & 599.6 & 73.0 & 5.0 & 2.4 \\
\hline 2010 & 635.6 & 89.7 & 3.7 & 3.4 \\
\hline
\end{tabular}

Source: Valsts regionālās ..., 2011.

and to prevent the formation of such disproportions in the future (Latvijas ilgtspējīgas ..., 2008).

The existing territorial disparities require purposeful national development policies, able to increase competitiveness of certain areas and even out the disparities which are hindering development. A prerequisite for sustainable municipal and regional development is the balance of socio-economic development and environmental interests. In addition, successful development of the area is unthinkable without involvement of the interested sides and considering the needs of local inhabitants, enterprises and organizations (LZA Ekonomikas ..., 2011).

The competition for investments is growing in the world, and the quality of the business environment in a particular territory plays a decisive role. In the World Bank's "Doing Business 2011" index (2010), Latvia is the 24th among 183 countries, stepping up by three places in the overall assessment compared to the previous year. Yet still, such indicators as termination of the businesses, payment of taxes, and business start-ups are the areas where it is necessary to continue reforms to make the Latvian business environment more attractive to both local entrepreneurs and foreign investors (Latvijas Republikas Ekonomikas ..., 2010).

Regional policy is very closely related to tax policy, being directed towards balanced regional development; however, development can be achieved through the promotion of entrepreneurship, as it creates new jobs (Fig. 1). Only strong governmental support for entrepreneurship and specific activities to promote economy will allow restoring sustainable development of the state, ensuring steady growth of the regions, a major local and foreign investment, resulting in increased wages and tax revenues for the state budget.

In order to stimulate the economic development of the regions, such economic mechanisms should be stimulated which can substantially increase the turnover of the economy and promote economic optimism both in employees and in employers. Only realization of such measures could result in a significant decline in unemployment, creation of jobs, and increase in household incomes.

The level of financial autonomy, stability and capacity of each local government is characterized by its tax revenue, which accounts for the most part of the total municipal budget (Table 1). In Latvia 
Local government general budget revenue in 2009-2010, million LVL

\begin{tabular}{lccccc}
\hline \multirow{2}{*}{$\begin{array}{c}\text { General budget } \\
\text { revenue indicators }\end{array}$} & $\begin{array}{c}\text { Performance, } \\
\text { million LVL }\end{array}$ & $\begin{array}{c}\text { \% of budget } \\
\text { revenues } \\
\text { (gross) }\end{array}$ & $\begin{array}{c}\text { Performance, } \\
\text { million LVL }\end{array}$ & $\begin{array}{c}\text { \% of budget } \\
\text { revenues } \\
\text { (gross) }\end{array}$ & $\begin{array}{c}\text { Changes } \\
\text { compared to } \\
2009, \%\end{array}$ \\
\hline Tax revenue & 677.64 & 45.0 & 729.22 & 53.3 & 7.6 \\
\hline Non-tax revenue & 39.12 & 2.6 & 31.04 & 2.3 & -20.7 \\
\hline $\begin{array}{l}\text { Service charges and } \\
\text { other revenues }\end{array}$ & 98.55 & 6.5 & 85.80 & 6.3 & -12.9 \\
\hline $\begin{array}{l}\text { Foreign financial } \\
\text { assistance }\end{array}$ & 0.94 & 0.1 & 0.89 & 0.1 & -5.3 \\
\hline Transfers & 689.81 & 45.8 & 522.03 & 38.1 & -24.3 \\
\hline Total revenue (gross) & 1506.07 & 100.00 & 1368.98 & 100.00 & -9.1 \\
\hline
\end{tabular}

Source: Valsts reǵionālās ..., 2011.

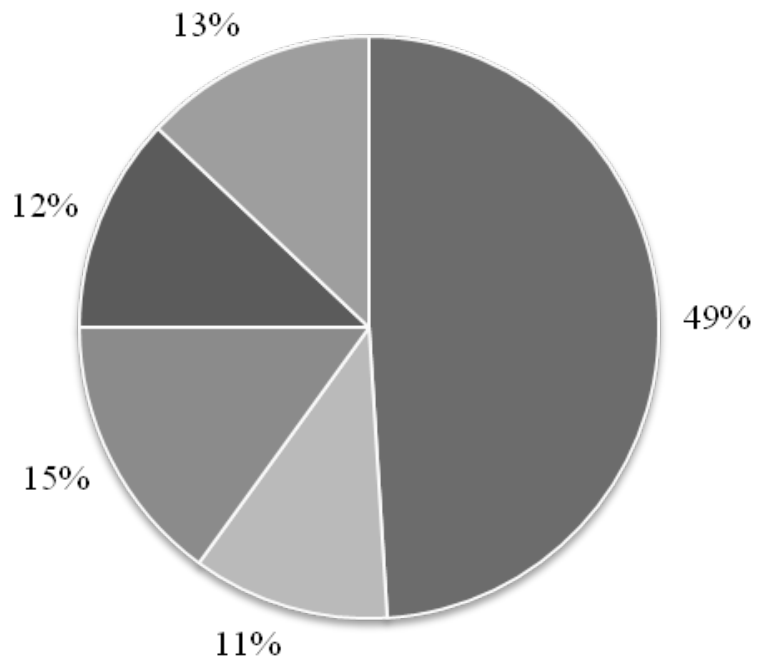

Riga region

Vidzeme region

Latgale region

$\square$ Zemgale region

Kurzeme region

Source: Valsts reǵionālās ..., 2011.

Fig. 2. Municipal general budget of the 2010 total revenues broken down by planning regions, $\%$.

all taxes are state taxes and no tax has been fixed as municipal tax. Municipal budgets receive partial revenue from personal income tax, lottery and gambling tax and environmental tax as well as full amount of property tax revenue. In 2010, the amount of tax revenue in the local government general budget was LVL 729.22 million (Table 2). The personal income tax revenue accounts for the major part of tax revenue in the local government budgets - in 2010 it was LVL 635.59 million a year, or $87 \%$ of the total tax revenue of local government budgets. The real property tax revenue in 2010 constituted $12.3 \%$ of tax revenues included in local government budgets. The proportion of revenue from lottery and gambling tax in local budgets is relatively small; in 2010 it amounted to less than half a percent of total tax revenues
(3.65 million LVL). In addition, lottery and gambling tax revenue is more typical for big cities, and there are a number of regional municipalities where this tax revenue is not collected at all. The amount of the revenue from the natural resource tax in local budgets is relatively small; in 2010 it accounted for less than half a percent of total tax revenue (3.39 million LVL) (Valsts reǵionālās ..., 2011).

The breakdown of the local government general budget revenue by planning regions explicitly demonstrates the Latvian regional differences (Fig. 2). In 2010, 49.1\% of the total local government general budget constituted the revenue of Riga region, $14.5 \%$ - of Latgale region, $13.0 \%$ - of Kurzeme region, $12.3 \%$ - of Zemgale region, and $11.0 \%$ of Vidzeme region (Valsts reǵionālās ..., 2011). In 
Table 3

Municipal budget and the amount of tax revenue, broken down by planning regions in 2010

\begin{tabular}{lcccccc}
\hline \multicolumn{1}{c}{ Data } & \multicolumn{5}{c}{ Planning region } \\
\cline { 2 - 7 } & Riga & Vidzeme & Kurzeme & Zemgale & Latgale & Latvia \\
\hline $\begin{array}{l}\text { General budget revenues, } \\
\text { million LVL }\end{array}$ & 672.6 & 151.08 & 178.56 & 168.39 & 198.35 & 1369.98 \\
\hline Tax revenue, million LVL & 452.9 & 57.06 & 79.34 & 76.31 & 63.61 & 729.22 \\
\hline $\begin{array}{l}\text { Proportion of tax revenue } \\
\text { in general budget revenues, } \%\end{array}$ & 67.3 & 37.8 & 44.4 & 45.3 & 32.1 & 53.3 \\
\hline $\begin{array}{l}\text { General budget revenues } \\
\text { per capita, LVL }\end{array}$ & 614 & 653 & 601 & 606 & 592 & 612 \\
\hline \begin{tabular}{l} 
Tax revenue per capita, LVL \\
\hline
\end{tabular} & 413 & 247 & 267 & 275 & 190 & 326 \\
\hline
\end{tabular}

Source: Valsts regionālās ..., 2011.

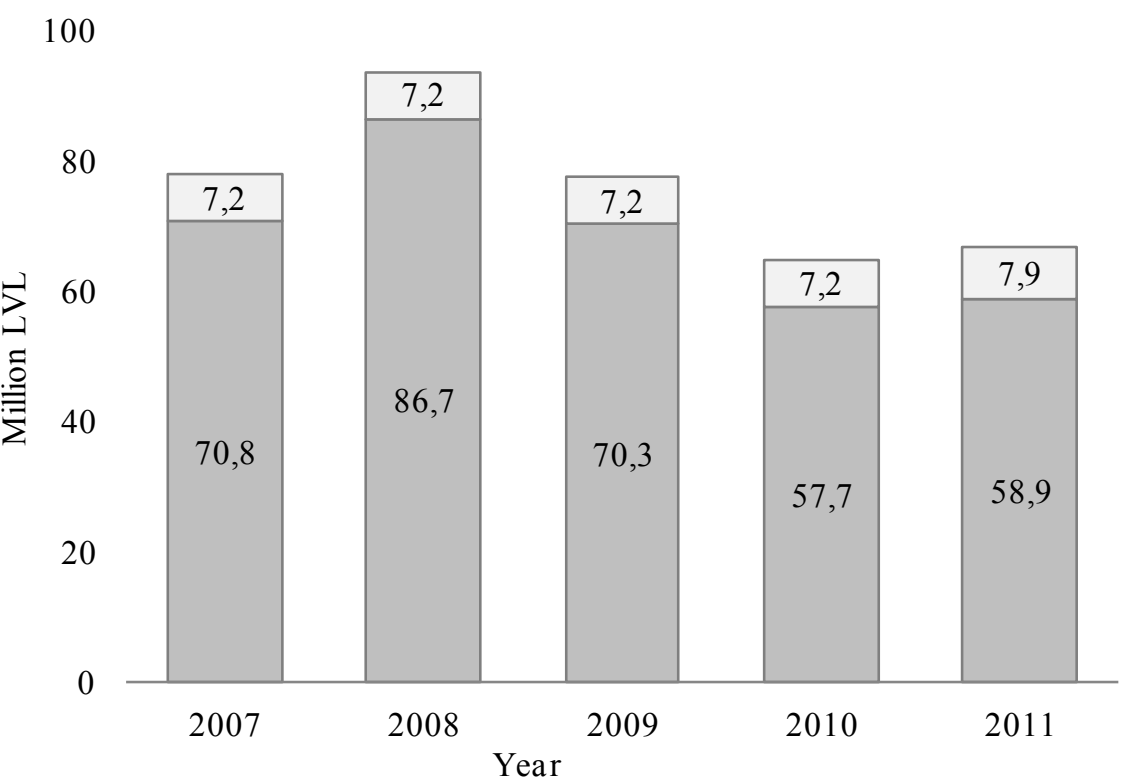

$\square$ State subsidies $\square$ Contributions of local governments

Source: Valsts kase, 2011.

Fig. 3. Dynamics of the local government financial equalization fund revenue for 2007 to 2011, million LVL (for the year 2011 - planned revenues).

2010, tax revenue constituted the bulk of the local government general budget revenue, i.e. $53.3 \%$; the next largest group was the revenue transfers $-38.1 \%$, service charges and other revenues accounted for $6.3 \%$, non-tax revenue $-2.3 \%$ of budget revenues, while a relatively small proportion was the foreign financial assistance income group - it did not exceed a tenth of a percentage (Valsts regionālās ..., 2011) (Table 2).

Since in Latvia there exist significant differences between the amounts of local government tax revenues, there are also big differences in the levels of socioeconomic development between municipalities. In
2010, tax revenue share of local government general budget ranged from $16 \%$ in Baltinava region to $86 \%$ in Garkalne region, but per capita tax revenues of the local government general budget were ranging from LVL 123 in Zilupe region to LVL 518 in Garkalne region (Valsts regiionālās ..., 2011). The summary of the local government tax revenue by planning regions shows that they are significantly higher in Riga region than in other regions. In 2010, the figure of Riga region was LVL 413 per capita, while in Latgale region, tax revenue was significantly lower - LVL 190 per capita (Valsts reǵionālās ..., 2011) (Table 3). 
Transfers to local government general budget revenue in 2009 and 2010, million LVL

\begin{tabular}{lccccc}
\hline \multirow{2}{*}{$\begin{array}{l}\text { General budget } \\
\text { revenue indicators }\end{array}$} & $\begin{array}{c}\text { Performance, } \\
\text { million LVL }\end{array}$ & $\begin{array}{c}\text { \% of budget } \\
\text { revenues (gross) }\end{array}$ & $\begin{array}{c}\text { Performance, } \\
\text { million LVL }\end{array}$ & $\begin{array}{c}\text { \% of budget } \\
\text { revenues } \\
\text { (gross) }\end{array}$ & $\begin{array}{c}\text { Changes } \\
\text { compared to } \\
2009, \%\end{array}$ \\
\hline PFIF & 75.32 & 5.0 & 64.77 & 4.7 & -14.0 \\
\hline $\begin{array}{l}\text { Transfers from } \\
\text { the state budget }\end{array}$ & 449.68 & 29.9 & 442.96 & 32.3 & -1.5 \\
\hline $\begin{array}{l}\text { Including } \\
\text { earmarked } \\
\text { subsidies }\end{array}$ & 334.07 & 22.2 & 229.39 & 16.7 & -31.3 \\
\hline $\begin{array}{l}\text { For EU structural } \\
\text { funds projects }\end{array}$ & 98.81 & 6.6 & 146.26 & 10.7 & 48.0 \\
\hline $\begin{array}{l}\text { Municipal budget } \\
\text { transfers }\end{array}$ & 164.81 & 10.9 & 14.30 & 1.0 & -91.3 \\
\hline \begin{tabular}{l} 
All transfers \\
\hline
\end{tabular} & 689.81 & 45.8 & 522.03 & 38.1 & -24.3 \\
\hline
\end{tabular}

Source: Valsts reǵionālās ..., 2011.

One of the most important regional development instruments, aimed at reducing the negative difference between the municipalities, is the local government financial equalization system. The local government financial equalization, taking into account various local government tax revenues as well as the different needs determined by the structure of the population, is currently being implemented through the local government financial equalization fund (PFIF). The fund is formed by the contributions of local governments and state subsidies (Fig. 3).

Although PFIF generally represents about 5\% of all local government general budget revenue and the main contributors are the local governments themselves, for many local governments this is one of the most important sources of revenue. The local government financial equalization fund experienced steady growth, reaching its peak in 2008, but in 2010 it started to decline.

The proportion of transfers in municipal budgets (Table 4) in 2010 was $38.1 \%$ (LVL 522.03 million); compared to 2009, it had declined by $24.3 \%$. The majority of transfers came from the state budget, including earmarked subsidies (LVL 229.39 million) and EU structural funds projects (LVL 146.26 million). Compared to 2009, the transfer reduction in 2010 (LVL 14.3 million) can be explained by the municipal mergers and liquidation of several municipalities, resulting in dramatic reduction of mutual payments between the governments (Valsts reǵionālās ..., 2011).
In 2010, the local government financial equalization calculations were included in the Cabinet Regulation No. 1571 "On the local government equalization fund revenues and their allocation in 2010" adopted on December 22, 2010 (Ministru kabinets, 2009) in accordance with the law "On Equalisation of Municipal Finance" (Par pašvaldību finanšu ..., 1998). According to the Regulation, the subsidy of the state budget into the financial equalization fund constituted LVL 7.1529 million, but the municipal contributions to the equalization fund were LVL 60081 million. In 2010, the same as in 2009, the actual PFIF was less than set before by the Cabinet of Ministers. The actual amount of PFIF in 2010 amounted to LVL 64.88 million, where the local government contribution was LVL 57.73 million. Contributions to the Fund in 2010 were made by 19 municipalities, among them five cities; 10 municipalities were in a neutral position, while the remaining 89 municipalities received a grant from the Fund. The main PFIF donor was the Riga City Council, whose contributions to the fund in 2010 were LVL 44.13 million, i.e., LVL 63 per one Riga resident.

Among the regions, a major contributor was Kekava region - LVL 1.23 million (LVL 56 per capita). By contrast, the largest per capita contribution was made by Babite region - LVL 69 per capita. The largest subsidy from the Fund was received by Rezekne district - LVL 4.45 million (LVL 142 per 
Table 5

Contributions to local government financial equalization fund, and grants from the fund in 2010 , broken down by planning regions

\begin{tabular}{lccccc}
\hline \multirow{2}{*}{ Data } & \multicolumn{5}{c}{ Planning region } \\
\cline { 2 - 6 } & Riga & Vidzeme & Kurzeme & Zemgale & Latgale \\
\hline $\begin{array}{l}\text { Total amount of contributions, } \\
\text { million LVL }\end{array}$ & 54.594 & 0.601 & 1.396 & 1.142 & - \\
\hline $\begin{array}{l}\text { Total subsidies received, } \\
\text { million LVL }\end{array}$ & 3.996 & 13.252 & 11.744 & 8.28 & 27.033 \\
\hline $\begin{array}{l}\text { Contribution/subsidies balance, } \\
\text { million LVL }\end{array}$ & -50.598 & 12.651 & 10.348 & 7.139 & 27.033 \\
\hline $\begin{array}{l}\text { Contribution/subsidies balance } \\
\text { per capita, LVL }\end{array}$ & -46.2 & 54.7 & 34.8 & 25.7 & 80.7 \\
\hline $\begin{array}{l}\text { Regional territory development } \\
\text { level index according to the 2009 data }\end{array}$ & 0.786 & -0.724 & -0.577 & -0.454 & -0.838 \\
\hline
\end{tabular}

Source: Valsts kase, 2011.

capita), but the largest grant per capita went to Riebini region and Varkava region - LVL 170 to each (Valsts reǵionālās ..., 2011). Financial equalization data collection according to planning regions indicates that in total (sum of contributions and subsidies) Riga region contributes to the Fund more than it receives, while the other four regions receive more subsidies from the Fund than they contribute to it. In Latgale region, not a single municipality contributes to PFIF. It should be noted that there is a strong correlation between the total of subsidies received by the planning region and the level of the territorial development index - the lower the index value, the greater the subsidy received (Table 5).

In order to increase the stability of the local government budgets, it is essential to achieve real independence of the budgets of local governments by reinforcing their independent sources of revenue. Reallocation of resources via the Financial Equalization Fund over the years has not led to financial stability of the local governments in the depressive regions; moreover, to some extent, it has even hindered the independence of donor municipalities as the mobilization of the financial resources limits the ability of local government to use freely their own resources (Zamyatina, 2010). Lack of revenue sources to cover the local costs and dependence on public support makes local governments financially unstable. The main source of the municipal budget revenue is tax revenue; however, the proportion of state and local transfers is almost as high. Thus, the more stable part of the local government revenue, in fact, depends directly on the tax policy implemented in the country. Local government budget revenue structure analysis indicates that the sources of the local government budget constitute more than a half of all revenues. The attachment of the local budget revenue base only to one particular, although a stable revenue source, is economically inefficient and associated with the risk of losing neutrality of the local government budget.

The economic downturn in 2008-2010 showed the weaknesses in the existing system of raising sources (tax revenue from state and local government budgets). While looking for solutions how to diversify risks, it would be advisable to determine for each level (state and local government) 2-3 stable sources of revenue with a different tax base. On the whole, such approach protects the budget during periods of economic crisis, because if there is a reduction in income from one tax base, it will be compensated by the revenue from another. In conditions when the budget revenue generating tax - personal income tax - is reducing, it cannot be compensated by other revenue sources at the disposal of local governments; as a result, the need arises to review local government budgets by attracting additional funding in the form of a transfer. The limited availability of taxes as a revenue source creates a chronic lack of financial resources, even in the large donor communities. The limited attraction of tax sources poses another risk: provisions are being incorporated in tax policies, depleting the resources of the tax base, such as property tax. Be aware that widening of the tax base does not address the stability of the local government budget; therefore, extension of the powers of tax administration at the municipal level still remains an important challenge (Zamyatina, 2010). 
The author considers the need for inclusion of the corporation income tax into the local government budgets as a sustainable and efficient solution, conducive to successful economic development. The attachment of this tax object would allow municipalities to effectively influence the formation of the tax base and to administer and support it successfully. The above mentioned solutions would notably reinforce the local government budget revenue base, increasing motivation of local governments into the development of enterprises on their territory, their modernization and attachment to the regions.

\section{Potential risks of including corporate income tax to municipal budgets}

Corporate profits in local governments are different, and in case of a superficial approach to the model, diversion of the corporate income tax (CIT) to local authorities can only increase the gap between the rich and the poor. A Lursoft study of the income return (profit minus loss) amount before tax, which is shown by the enterprises registered in the relevant local government in the period from 2007 to 2010, confirms the significant differences of corporate profits in local governments. The study included data about 73715 Latvian companies. In the 2010 accounting year, the total return of enterprises registered in 36 municipalities was negative (working with losses); moreover, in two municipalities - Marupe region and the city of Liepaja - the losses of the registered companies amounted to LVL 52.5 million and to LVL 45.3 million respectively. The most profitable return was registered in Riga enterprises LVL 62.2 million $(57 \%$ of all pre-tax profits in 2010), and in Ventspils - LVL 18.2 million (Brūvelis, Lēvalde, Igaune, Pankovska, \& Kirsons, 2012).

The Ministry of Environment and Regional Development (VARAM) holds a view that provides for partial diversion of CIT into the municipal budget (Brūvelis et al., 2012). The author's vision is - diversion of CIT from all companies (except the ones with state capital) into the budget of the local government on whose territory the enterprise has been legally registered. A Lursoft representative in the analysis of survey data raises a number of risks that may arise in income tax redistribution process (Brūvelis et al., 2012).

Differences, since CIT is a quite variable indicator, compared to personal income tax. Not only the population is different in Latvian municipalities, but also the number of the registered companies, their specialization, the number of employees and the total amount of profit.

Inclusion of CIT revenue of large taxpayers as it is not clear how to deal with the division of CIT part of the large Latvian companies, which could be diverted to the local governments. Such companies as $A S$ Latvijas meži, AS Latvenergo, AS Latvijas gāze, SIA Latvijas mobilais telefons, SIA Lattelecom, SIA Tele 2, and SIA Maxima Latvija have registered offices in Riga or Riga suburbs, but the actual economic activities are carried out on the municipal territories. The minister of Environmental Protection and Regional Development as a solution to this risk suggests to leave the large publicly owned companies out of the framework of regulation or to determine the distribution, for example, into branches.

Easily to be circumvented, because the CIT is a tax from which companies can avoid most easily. The authors of the Lursoft study consider that since earnings may change significantly, planning of the tax revenue in a long term is not possible, like, for example, in Marupe region where the total revenue balance of the registered companies was LVL 82.7 million in 2007, but in 2010 there were LVL 52.4 million of losses; as well as in Riga, where in 2009 the losses were 700 million LVL as opposed to the enormous profit of LVL 1.38 billion in 2007.

In order to divert the corporate income tax revenue without interfering with the businesses, the Lursoft expert offers to redistribute the CIT revenue by attributing the CIT revenue to the worker's actual address, so that the regions in which people are employed, for example, in a structural unit of a company registered in Riga, would receive additional income. However, such approach, according to the author, would raise the costs of tax administration. As a further threat to the corporate income tax framework, the authors see the CIT advance payments and their repayments, in case of the company's profit shortfall. Currently, tax repayment is centralized, but there is no unanimous opinion who will reimburse the tax if the revenue is re-allocated to the local government.

The authors of the Lursoft study see the solution of the attachment of CIT in the fixed tax, arguing that such an approach would limit tax evasion. Entrepreneurs, in their turn, are cautious regarding the increase of the local government mandate, claiming that such reform could lead to the situation when the wealthy local governments will be able to give more condescensions (require lower taxes and offer higher discounts) than the poor municipalities and the financially stronger local governments will win the 
competition for investments. In order to implement the idea of inclusion of CIT into local government budgets, the authors of Lursoft study hold a view that alignment of local governments is necessary (Brūvelis et al., 2012).

\section{The possible solutions of attaching corporate income tax to municipal budgets}

Additional tax policy instruments: diverting the corporate income tax and personal income tax to local government budgets in the long run could replace transfer payments, leaving only the option to make necessary adjustments (within the framework of increase or decrease). If the amount of transfers increases, the budget review takes place only within the amount of the increase; if the amount of transfers is declining, then it only evidences the efficiency of the norms to be implemented by the tax policy.

If looking for solutions how to reinforce the local government budgets through fiscal policy is neglected, the economic instability, high unemployment and, as a result, reduction in budget revenues from personal income tax will inevitably leave a negative impact on the changes in interbudgetary transfers in the local budget revenues.

In its turn, the increase in the share of transfers in the structure of the local government budget revenue, along with simultaneous reduction of tax and nontax revenue in these budgets, limits the possibilities of local governments to determine priorities for the expenditure part, as well as negatively affects the amount of the local government budget deficit and its debt levels.

At the same time, it is necessary to minimize the subsidies to the local governments, shifting the focus from targeted transfers to the sources of revenue which local governments are free to act with in addressing their socio-economic needs. This will increase local autonomy, and the fiscal/ financial mobility of several local governments, which is particularly important in the case of fund shortfalls; reduce administrative costs and significantly reduce the amount of financial documents relating to applying for subsidies and demanding accountability for the funds. Of course, this relates to delegation of special mandate (applying discounts) to local authorities, which would make them mutually more competitive.

Such changes are associated with the need to reform the tax system so that businesses in planning regions could affect their administrative budget. Diversion of corporate income tax to municipalities in planning regions could significantly affect the motivation of regions to attract as many entrepreneurs as possible to their administrative territories by applying favourable tax policies.

Situations cannot be permitted when tax incentives are allocated to a sector rather than to a particular company, depending on its location, because then no company will be eager to build its plant in a place which is far from the currently most advanced region, and regional socio-economic inequalities will continue to increase. Motivation for companies should be created to build in places where markets are currently limited and infrastructure is underdeveloped. The German example of regional development has shown that a multi-tax system is likely to smooth out the social and economic inequalities. Also, another state, Italy, where regional policy is one of the priorities, is working on the introduction of fiscal federalism. In Latvia such multilevel system is not required because of its small size, but delegation of some fiscal functions (CIT allowances, other incentives) to local governments is absolutely essential in developing business environment.

In order to avoid circumvention of CIT, it is recommended to set a monthly tax period (Estonia's example), which would mutually benefit both the taxpayers, because then business revenues will not have to be diverted unduly into CIT advance payments, and the tax administrators, because then tax rebate will not have to be done in the post-taxation period.

The procedure of corporate income tax advance refund would be simplified as well in case of revenue reduction. Diversion of CIT into the municipal budget could be as a solution for the administration of repayments; repayment could be made from the same municipal budget where payment has been received. For this purpose, the municipal budgets would need to build a reserve to ensure operative reimbursement. In turn, companies whose amount of corporate income tax for the taxable year does not exceed LVL 1000 should be allowed not to make advance payments; thus small businesses would be motivated, because the advance payment is a heavy burden for them; the money could be invested in the development instead.

Another solution how to increase tax revenues is creation of favourable environment for small and medium business development because this sector can best react to changes in demand. Reinforcement 
of fiscal autonomy of local government budgets depends entirely on the tax strategy, which in 2011 set regional development as one of the key issues in the country.

\section{Conclusions}

1. The Ministry of Finance of the Republic of Latvia in its Tax Policy Strategy for the 20112014 has set as one of its priorities the task to promote motivation of local governments to develop business environment.

2. One of the most important regional development instruments aimed at reducing the negative differences between the municipalities is the local government equalization system, which exercises the local government equalization fund. Such regional development tool does not create interest in the local governments into business development in their territory.

3. The financial autonomy, stability and capacity level of each local government accounts for the majority of the total municipal budget. As there are significant socioeconomic gaps in the development of local governments in Latvia, there is also a large gap between the local tax revenues. Reallocation of resources to finance the equalization fund in the course of several years has not made local governments in the depressed regions financially more stable and even to some extent has hindered the independence of the donor municipalities.

4. The financial autonomy and stability of local governments can be implemented by expanding the mandate of tax administration on the level of local governments.

5. According to the author's estimation, inclusion of corporate income tax into the local government budgets would be a sustainable, efficient, and economy developing solution. It would allow municipalities to effectively influence the formation of the tax base, administer and support it successfully.

6. Additional tax policy instrument - diverting the corporate income tax of all enterprises as well as personal income tax to local government budgets - in the long run could replace transfer payments, leaving only the option to make necessary adjustments (within the framework of increase or decrease).
7. Determining a monthly tax period will prevent such threats in corporate income tax regulations as complicated administration of CIT advance payments and repayments (in case of a decrease in company's revenue).

\section{References}

1. Brūvelis, A., Lēvalde, V., Igaune, S., Pankovska E., \& Ķirsons, M. (2012, February 14). Pẹ̦nas nodoklis - vietējai pašvaldībai - iespēja vai drauds. Dienas Bizness, 8-9. lpp.

2. Eiropas Komisija. (2010). Stratēgija gudrai, ilgtspējīgai un integrējošai izangsmei. Eiropa 2020. Komisijas pazinojums. Briselē, 03.03.2010, COM (2010) 2020 galīgā redakcija. Retrieved from http://ec.europa.eu/eu2020/ pdf/1_LV_ACT_part1_v1.pdf

3. Eiropas Kopienu Komisija. (2005). Istenojot Kopienas Lisabonas programmu: Komisijas pazinojums padomei un Eiropas Parlamentam, Nodokļu un muitas politikas ieguldījums Lisabonas stratēgijā. Briselē, 25.10.2005, COM (2005) 532 galīgā redakcija. Retrieved from http:// eur-lex.europa.eu/LexUriServ/LexUriServ. do?uri=COM:2005:0532:FIN:LV:PDF

4. Latvijas ilgtspējiggas attīstības stratēgija lìdz 2030. gadam. (2008). Retrieved from http:// www.latvija2030.lv/upload/ministriju_un_ regionalo_strategiju_parskats.pdf

5. Latvijas Republikas Ekonomikas ministrija. (2010). Latvijas nacionālā reformu programma "ES 2020" stratēgijas istenošanai. Valsts kanceleja Rīgā, 16.11.2010. Retrieved from http://polsis.mk.gov.lv/view.do?id=3517

6. LR Finanšu ministrija. (2011). Nodokļu politikas stratēgija 2011.-2014. gadam. Retrieved from http://www.fm.gov.lv/lv/ sadalas/nodoklu_politika/nodoklu_politikas_ strategija_2011_2014_gadam

7. LZA Ekonomikas institūts. (2011). Latvijas regionu ekonomikas attīstības perspektīvas un virzieni 2010-2011. Retrieved from www.varam.gov.lv/in_site/tools/download. php?file=files/text

8. Ministru kabinets. (2009). Noteikumi par pašvaldību finanšu izlīdzināšanas fonda ieñèmumiem un to sadales kārtību 2010. gadā. MK 2009. gada 22. decembra noteikumi Nr. 1571. Retrieved from http://www.likumi.lv/ doc.php?id=202809 
9. Ministru kabinets. (2011). Par Latvijas Stratēgiskās attīstības plāna 2010.-2013. gadam uzdevumu un darbības rezultātu ìstenošanu kārtējā pārskata periodā. Retrieved from http:// www.likumi.lv/doc.php?id=208079

10. Organisation for Economic Co-operation and Development. (2006). The New Rural Paradigm: Policies and Governance. OECD Rural Policies Reviews. OECD Publishing. Retrieved from http://isbndb.com/d/book/ oecd_rural_policy_reviews_the_new_rural_ paradigm_policies_an.html

11. Par pašvaldību finanšu izlīdzināšanu. (1998). LR likums. Retrieved from http://www.likumi.lv/ doc.php?id $=47361 \&$ version_date $=01.04 .1998$
12. The World Bank. (2010). Doing Business 2011. Making a Difference for Entrepreneurs. IFC. 2010. The International Bank for Reconstruction and Development. Washington: The Office of the Publisher, the World Bank.

13. Valsts kase. (2011). Valsts kases publiskais gada pārskats par 2010. gadu. Retrieved from www.kase.gov.lv/texts_files/Valsts\%20kase_ net_LV.pdf

14. Valsts reǵionālās attīstības aǵentūra. (2011). Regionu attīstība Latvijā 2010. Retrieved from http://www.vraa.gov.lv/uploads/1-2_lv.pdf

15. Zamyatina, N. (2010). Ways to rise stability of local budgets. Region: Economics and sociology, 3, 237-248. (In Russian).

\section{Acknowledgements}

Publication is the result of participation in European Social Fund project "Support for LLU in doctoral studies implementation" within the (sub-activity 1.1.2.1.2. Support for implementation of a doctoral study program 2009/0180/1DP/1.1.2.1.2/09/IPIA/ VIAA/017) contract No. 04.4-08/EF2.D2.23. 